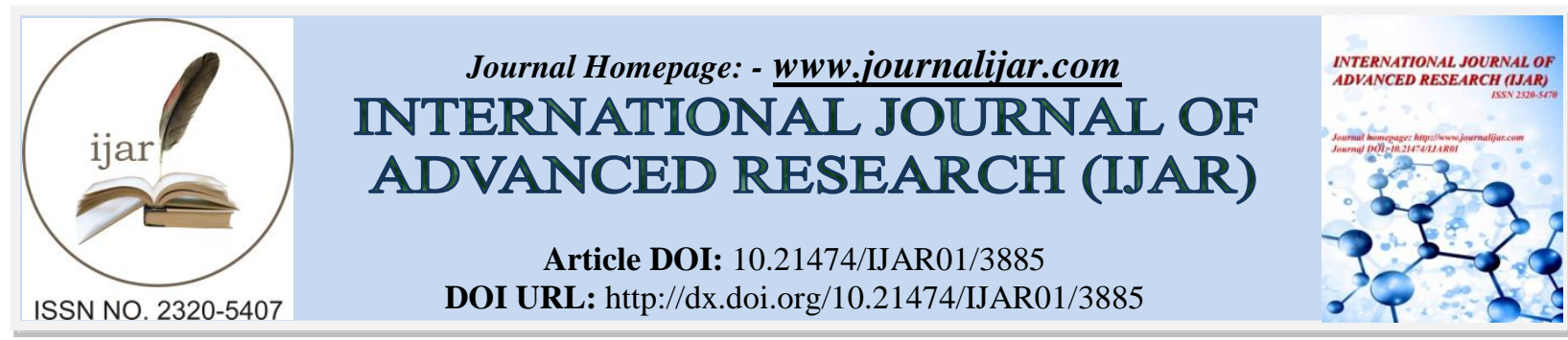

RESEARCH ARTICLE

\title{
THE NURSING STUDENT'S ATTITUDE TOWARD PSYCHIATRIC PATIENTS: IS CHANGEABLE AFTER COMPLETING THE THEORETICAL AND CLINICAL COURSE.
}

\author{
Rania Rabie El-Etreby. Lecturer ${ }^{1}$, Mohamed Mahmoud Shahda. Professor ${ }^{2}$ and Adel Al- Wehedy Ibrahim. \\ Professor $^{3}$ \\ 1. Psychiatric and Mental Health Nursing, Faculty of Nursing, Mansoura University. \\ 2. Psychiatric Medicine, Faculty of Medicine, Mansoura University. \\ 3. Public Health Department, Faculty of Medicine, Mansoura University.
}

\section{Manuscript Info}

n......................

Manuscript History

Received: 08 February 2017

Final Accepted: 05 March 2017

Published: April 2017

Key words:-

attitude, nursing students, psychiatry and mental illnesses

\section{Abstract}

Introduction: Attitude to psychiatry and mental illness among nursing students are key factors in determining their choice of psychiatric nursing as a career and willingness to deal with psychiatric disorders in general practices.

Aim: to identify nursing student's attitudes toward psychiatry before and after the psychiatric nursing course (theoretical and clinical course), and to assess their intention to choose psychiatric nursing as a future career.

Methods: a quasi-experimental design was used in this study. The sample consisted of 70 nursing students enrolled in the psychiatric and mental health nursing course for the academic year 2014- 2015. The course consists of two parts the theoretical and the clinical part. Students were asked to complete the questionnaires used in this study at the beginning of the course and again at the end of the course. The methods of data collection include socio- demographic characteristics of the students, and attitude toward psychiatry (ATP 30).

Results: There was slight improvement in the average total attitude score of the students after studying the course, with no significant difference, and the nursing student's intention to choose psychiatric nursing as a career in the future was raised after the course with significant difference.

Conclusion: the total attitude score of the nursing students attitude towards psychiatric patients has been slightly improved, also the students intention to choose psychiatric nursing as a career has been improved after the psychiatric nursing course.

Copy Right, IJAR, 2017,. All rights reserved.

\section{Introduction:-}

Psychiatric nurses are a major member of the mental health-care team. They play different roles ranging from that of a case manager to a source of emotional support in the therapeutic process ${ }^{(1)}$. The nature of nursing profession requires nurses to spend more hours with the patients than all other health care professionals ${ }^{(2)}$.

The shortage of psychiatry nurses has been found all over the world, this shortage may be due to that nursing students have negative attitudes toward psychiatric patients and this lead to elect out of psychiatric placements ${ }^{(3)}$. 
This negative attitudes have been shown to have a negative effect on the therapeutic relationships and treatment outcomes $^{(4)}$.

Attitude has been defined as "an emotionally linked, learnt belief around an object or situation predisposing one to respond in some Preferential way" (5). Mental health professionals, the subject of psychiatry, psychiatrists and the psychiatric ill patients are affected by the negative attitude and the cultural stereotypes of the general public. Health care team are not immune to social prejudices and share the general public's attitude toward people with mental illness ${ }^{(6)}$. Unfortunately, this negative attitudes toward mentally ill is not in doubt even among nursing students that lead to a major effect on the quality and outcome of care for psychiatric ill patients ${ }^{(7)}$.

Many researchers found a relationship between nursing students' attitudes and courses in psychiatric nursing. Students starting the nursing course with negative attitude to psychiatric ill patients, thus showing lack of knowledge as to their possibilities of recovery and social living. Clinical experience has been always an integral part of nursing education. It prepares student nurses to be able of "doing" as well as "knowing" the clinical principles in practice. The clinical practice stimulates students to use their critical thinking skills for problem solving (8\&9). Many researchers revealed that excessive exposure to psychiatry during clinical experience has a positive effect on students' attitude towards psychiatry and a career choice of the discipline, interactions and contact with mentally ill patients reduce anxiety and fear and may lead to change the students' attitude in a more positive way, however other show that such exposure could have a minimal effect ${ }^{(10)}$.

Many studies showed that undergraduate nursing students have negative attitudes toward psychiatric and mental health nursing as a career, that make psychiatric nursing unpopular and not viewed as a favorable career choice ${ }^{(11)}$. Attitudes towards psychiatry and a career choice in psychiatry have many factors including demographics, social variables, personality and concern for the mentally ill ${ }^{(12 \& 13)}$.

Psychiatric nursing has gained an increasing importance in nursing undergraduate curricula all over the world in the last few decades. According to this new trend, Faculties of nursing give more time for teaching psychiatric nursing through lecturers, small group discussion, and problem based learning and clinical experience. During the clinical rotation they are exposed to acute in-patient psychiatry, out-patient psychiatry, and community psychiatry and addiction medicine ${ }^{(14)}$.

Aim of the study: -

The current study aimed to identify the baccalaureate nursing students' attitudes toward psychiatry before and after the psychiatric nursing course (theoretical and clinical course), and to assess their intention to choose psychiatric nursing as a future career.

Methodology:-

Research design:

A quasi- experimental research design was used in this study.

\section{Research Question:-}

$>$ Is there a change in the baccalaureate nursing students' attitudes toward psychiatry before and after the psychiatric nursing course (theoretical and clinical course)?

$>$ Is there a change in the baccalaureate nursing student's intention to choose psychiatric nursing as a future career after the psychiatric nursing course?

\section{Setting:-}

The current study was conducted at the Faculty of Nursing, Mansoura University, Egypt. The faculty has eight different scientific nursing departments, among which is the psychiatric and mental health nursing department. One of the main courses taught by the psychiatric and mental health nursing department is the psychiatric and mental health nursing.

\section{Subjects:-}

A random sample of 74 nursing students registered in the psychiatric and mental health nursing course for the academic year 2014- 2015. The course consists of two parts, 15 weeks (60 hours) for the theoretical part and 15 
weeks (180 hours) for the clinical part of the course. Four students were excluded from the study due to their absenteeism, so the sample size became 70 students.

\section{Tools of data collection:-}

- Socio-demographic characteristics of the students such as age, sex, residence and socio economic status evaluation using Socioeconomic scale ${ }^{(15)}$, in addition to the students' opinion to choose psychiatric nursing as a career in the future.

- Attitudes towards psychiatry $\left(\right.$ ATP-30) ${ }^{(16)}$ :

The 30 items attitude scale was used to measure attitudes towards many aspects of psychiatry; attitudes toward psychiatric patients and mental illness, psychiatry, psychiatric knowledge and teaching and psychiatric treatment and hospitals through 5- point likert rating scale namely, strongly disagree $=1$, disagree $=2$, neutral $=3$, agree $=4$ and strongly agree $=5$. Scores ranges from 30-150, divided into, negative attitude $=30$, neutral attitude $=90$ and positive attitude $=150$, the higher the score, the more favorable the attitude.

\section{Methods of data Collection:-}

Official permission was obtained from the responsible authorities of the Faculty of Nursing, Mansoura University, Egypt to conduct the study. Tool 2 was translated into Arabic language and it was tested for its content validity by a jury of 5 experts in the psychiatric medical and nursing field and proved to be valid. Pilot study was carried out on 15 nursing students from the third grade in order to test the reliability, clarity and applicability of the study tool and it was revealed that tool was clear and applicable and its (Cronbach's alpha=0.76). Students were asked to complete the study tools used at the beginning of the course and again at the end of the course under supervision of the researcher.

\section{Ethical consideration:-}

Throughout the study phases:-

$>$ Ethical consideration was obtained from the Research Ethics Committee of the faculty of Nursing, Mansoura University.

$>$ Verbal informed consent to voluntary participate in the study was obtained from the nursing students after explanation of its aim.

$>$ Students' right to participate or withdraw from the study was emphasized after reassuring them that their responses would have no impact on their grades.

$>$ Students were re- assured that the collected data would be treated with confidentiality and it would be used only for the purpose of the research.

\section{Statistical Analysis:-}

Statistical Package for Social Sciences (SPSS) version 16.0 was used for the statistical analysis of the obtained data. Data were presented using descriptive statistics in the form of frequencies and percentages for qualitative variables and means \pm standard deviations for quantitative variables. Qui square test were used for comparison for qualitative variables while student $t$ test, one-way ANOVA (F) were used for comparison of quantitative variables. Statistical significance was considered at $\mathrm{P} \leq 0.05$.

\section{Results:-}

The majority of studied students were females 81.1 , from rural areas $(86.5 \%)$ and they were nearly four quarters from very low to high socio economic level (table1). Before the studying the psychiatric course, only $24.3 \%$ of them had an opinion to select psychiatric nursing as a career and it was raised to by $48.6 \%$ after the course with significant difference. The main cause of did not choosing it was warring that psychiatric patient is unsafe (35.7\%), the student was not interest in psychiatry $(32.1 \%)$, poor progress of psychiatric patients $(28.7 \%)$ and stigma towards psychiatric patients (26.8\%). And there was slight decrease of these percentages after studying the course (table 2).

Table 1:- Socio-demographic characteristics of the studied students

\begin{tabular}{|l|l|l|l|}
\hline Character & Items & No & $\%$ \\
\hline Sex & Males & 14 & 18.9 \\
& Females & 60 & 81.1 \\
\hline Resident & Rural & 64 & 86.5 \\
\hline
\end{tabular}




\begin{tabular}{|l|l|l|l|}
\hline & Urban & 10 & 13.5 \\
\hline SES* & Very low & 18 & 24.3 \\
& Low & 18 & 24.3 \\
& Moderate & 18 & 24.3 \\
& High & 20 & 27.0 \\
\hline
\end{tabular}

$* \mathrm{SES}=$ Socio Economic status

Table 2:- Percentages of choose psychiatric nursing among studied student before and after studying the course

\begin{tabular}{|l|l|l|l|l|l|}
\hline \multirow{2}{*}{ Intention } & \multicolumn{2}{l|}{ Pre $(74)$} & \multicolumn{2}{l|}{ Post (70) } & \multirow{2}{*}{ Significance test } \\
\cline { 2 - 5 } & No & $\%$ & No & $\%$ & \\
\hline Yes & 18 & 24.3 & 34 & 48.6 & $\chi^{2}=9.17, \mathrm{P} 0.002$ \\
No & 56 & 75.7 & 36 & 51.4 & \\
\hline Causes of non intention & 12 & 21.4 & 8 & 22.2 & $\chi^{2}=0.01, \mathrm{P} 0.928$ \\
\hline 1-Limits application of general nursing knowledge & 10 & 17.9 & 7 & 19.4 & $\chi^{2}=0.04, \mathrm{P} 0.848$ \\
\hline 2-Emotional tiring job & 16 & 28.7 & 9 & 25.0 & $\chi^{2}=0.14, \mathrm{P} 0.707$ \\
\hline 3-Poor progress of psychiatric patients & 14 & 25.0 & 12 & 33.3 & $\chi^{2}=0.58, \mathrm{P} 0.447$ \\
\hline 4-Difficult to manage other people emotional issues & 18 & 32.1 & 11 & 30.5 & $\chi^{2}=0.03, \mathrm{P} 0.873$ \\
\hline 5-No interest in psychiatry & 20 & 35.7 & 6 & 16.7 & $\chi^{2}=3.92, \mathrm{P} 0.047$ \\
\hline 6-Woring with psychiatric patients is unsafe & 15 & 26.8 & 7 & 19.4 & $\chi^{2}=0.65, \mathrm{P} 0.420$ \\
\hline 7-Stigmata towards psychiatric patients & 8 & 14.3 & 4 & 11.1 & $\chi^{2}=0.19, \mathrm{P} 0.659$ \\
\hline 8-Others & & & &
\end{tabular}

There was nearly no change in the average scores of the items of the students attitude towards psychiatrist and psychiatry after studying the course compared to their scores before it (table 3). There was a significant improvement of the averages scores of the attitude towards psychiatric patients and mental health like; Psychiatry is an esteemed specialty of medicine, Psychiatrist get less gratification from their work than other specialties, If I were asked to choose the three most interesting medical branches, psychiatry will be precluded and It is difficult to think of psychiatrists as equal to other doctors. Also, the total score was significantly improved (table 4). Out of 7 items of the attitude towards psychiatric knowledge and teaching, only three of them showed slight improvement after studying the course which includes: Most of nursing students revealed that their psychiatric illness under graduate training course has been valuable, Today psychiatry is the most important course among the different courses in medical schools and Psychiatry is so unscientific that even psychiatrists can't agree about its basic sciences. But the total score of the attitude towards psychiatric knowledge and teaching was not significantly changed (table 5). Table (6) showed that out of 8 items of the attitude towards psychiatric treatment and hospitals, only three of them showed slight improvement after studying the course which includes: Psychiatrist has very little to do to help their patients, The practice of psychotherapy basically is fraudulent since there is no strong evidence that it is effective and Psychiatric treatment has been more effective in the recent year while the total score of the attitude towards psychiatric treatment and hospitals was not significantly differed. There was slight improve in the average total attitude score of the students being $92.67 \pm 7.90$ before studying the course and $95.34 \pm 8.32$ after it, with no significant difference (table7). There were no significant changes between average total attitude score in relation to sex or residence before and after studying the course. While there was significant difference in the average total attitude score in different SES groups before studying the course and it was eliminated after it (table 8).

Table 3:- Average scores of the items of the attitude of the studied students towards psychiatrists and psychiatry before and after studying the course

\begin{tabular}{|l|l|l|l|}
\hline Items & Before & After & Significance test \\
\cline { 2 - 3 } & Mean \pm SD & Mean $\pm \mathrm{SD}$ & $\mathrm{t}=0.00, \mathrm{P} 1.00$ \\
\hline $\begin{array}{l}\text { Psychiatric nursing is unattractive branch } \\
\text { because it uses little nursing training. }\end{array}$ & $3.43 \pm 1.10$ & $3.43 \pm 1.03$ & $\mathrm{t}=1.421, \mathrm{P} 0.160$ \\
\hline $\begin{array}{l}\text { It is exciting to attempt to discover the cause } \\
\text { of a psychiatric disorder. }\end{array}$ & $3.48 \pm 0.86$ & $3.27 \pm 0.91$ & $\mathrm{t}=0.599, \mathrm{P} 0.578$ \\
\hline $\begin{array}{l}\text { Mentally ill patients are human like other } \\
\text { people, if we try to listen to them. }\end{array}$ & $3.84 \pm 0.94$ & $3.67 \pm 0.94$ & $\mathrm{t}=0.00, \mathrm{P} 1.00$ \\
\hline It is interesting to work with psychiatric & $3.53 \pm 1.09$ & $3.53 \pm 1.00$ & \\
\hline
\end{tabular}




\begin{tabular}{|l|l|l|l|l|}
\hline $\begin{array}{l}\text { patients rather than working with other } \\
\text { patients. }\end{array}$ & & & \\
\hline Total Score & $14.29 \pm 2.35$ & $13.99 \pm 2.74$ & $\mathrm{t}=0.764, \mathrm{P} 0.444$ \\
\hline
\end{tabular}

Table 4:- Average scores of the items of the attitude of the studied students towards psychiatric patients and mental illness before and after studying the course

\begin{tabular}{|c|c|c|c|}
\hline \multirow[t]{2}{*}{ Items } & Before & After & \multirow[t]{2}{*}{ Significance test } \\
\hline & Mean \pm SD & Mean \pm SD & \\
\hline $\begin{array}{l}\text { Psychiatric illness deserves more attention } \\
\text { like physical illness }\end{array}$ & $2.50 \pm 0.99$ & $2.57 \pm 1.04$ & $\mathrm{t}=0.413, \mathrm{P} 0.681$ \\
\hline Psychiatrist talk a lot but do very little & $2.62 \pm 1.02$ & $2.97 \pm 0.98$ & $\mathrm{t}=1.947, \mathrm{P} 0.056$ \\
\hline $\begin{array}{l}\text { Psychiatrist seem to talk about nothing but } \\
\text { sex }\end{array}$ & $2.97 \pm 1.13$ & $3.50 \pm 1.02$ & $\mathrm{t}=3.156, \mathrm{P} 0.002$ \\
\hline I would like to be a psychiatric nurse. & $3.06 \pm 1.21$ & $3.01 \pm 1.17$ & $\mathrm{t}=0.269, \mathrm{P} 0.789$ \\
\hline $\begin{array}{l}\text { Psychiatric nursing is an esteemed specialty } \\
\text { of nursing. }\end{array}$ & $3.97 \pm 0.93$ & $3.64 \pm 1.14$ & $\mathrm{t}=2.290, \mathrm{P} 0.025$ \\
\hline $\begin{array}{l}\text { Psychiatrist appear to be stable as the other } \\
\text { doctor }\end{array}$ & $3.50 \pm 0.88$ & $3.63 \pm 0.75$ & $\mathrm{t}=0.922, \mathrm{P} 0.360$ \\
\hline $\begin{array}{l}\text { Psychiatric nurses get less gratification from } \\
\text { their work than other specialties }\end{array}$ & $2.47 \pm 1.07$ & $2.97 \pm 1.05$ & $\mathrm{t}=2.769, \mathrm{P} 0.007$ \\
\hline $\begin{array}{l}\text { If I were asked to choose the three most } \\
\text { interesting nursing branches, psychiatric } \\
\text { nursing will be precluded. }\end{array}$ & $2.54 \pm 1.07$ & $2.91 \pm 1.13$ & $\mathrm{t}=2.480, \mathrm{P} 0.016$ \\
\hline $\begin{array}{l}\text { I think psychiatrists are not equal to other } \\
\text { doctors. }\end{array}$ & $2.62 \pm 0.96$ & $3.13 \pm 1.01$ & $\mathrm{t}=2.751, \mathrm{P} 0.008$ \\
\hline $\begin{array}{l}\text { On the whole. People taking up psychiatric } \\
\text { training are running medical training. Away } \\
\text { from participation in real medicine }\end{array}$ & $2.77 \pm 1.05$ & $2.87 \pm 0.84$ & $\mathrm{t}=0.662, \mathrm{P} 0.510$ \\
\hline $\begin{array}{l}\text { Psychiatric nursing is so unclear that it } \\
\text { cannot be really taught effectively }\end{array}$ & $2.81 \pm 1.07$ & $2.66 \pm 1.15$ & $\mathrm{t}=0.855, \mathrm{P} 0.396$ \\
\hline Total Score & $31.86 \pm 4.39$ & $33.87 \pm 4.83$ & $\mathrm{t}=2.606, \mathrm{P} 0.011$ \\
\hline
\end{tabular}

Table 5:- Average scores of the items of the attitude of the studied students towards psychiatric knowledge and teaching before and after studying the course

\begin{tabular}{|l|l|l|l|}
\hline Items & Before & After & Significance test \\
\cline { 2 - 3 } & Mean \pm SD & Mean \pm SD & $\mathrm{t}=2.089, \mathrm{P} 0.040$ \\
\hline $\begin{array}{l}\text { Most of nursing students revealed that their } \\
\text { psychiatric illness under graduate training } \\
\text { course has been valuable }\end{array}$ & $3.51 \pm 0.97$ & $3.19 \pm 0.94$ & $\mathrm{t}=0.720, \mathrm{P} 0.474$ \\
\hline $\begin{array}{l}\text { Psychiatry has very little scientific base to go } \\
\text { on }\end{array}$ & $2.88 \pm 1.12$ & $3.01 \pm 1.21$ & $\mathrm{t}=2.842, \mathrm{P} 0.006$ \\
\hline $\begin{array}{l}\text { Today psychiatric nursing the most important } \\
\text { course among the different courses in nursing } \\
\text { schools }\end{array}$ & $3.64 \pm 1.04$ & $3.20 \pm 1.02$ & $\mathrm{t}=2.734, \mathrm{P} 0.008$ \\
\hline $\begin{array}{l}\text { Psychiatry is so unscientific that even } \\
\text { psychiatrists can't agree about its basic } \\
\text { sciences }\end{array}$ & $2.69 \pm 1.08$ & $3.18 \pm 103$ & $\mathrm{t}=1.912, \mathrm{P} 0.060$ \\
\hline $\begin{array}{l}\text { The majority of the so called facts in } \\
\text { psychiatry are really just guess }\end{array}$ & $2.48 \pm 0.91$ & $2.74 \pm 0.77$ & $\mathrm{t}=0.320, \mathrm{P} 0.750$ \\
\hline $\begin{array}{l}\text { Psychiatric courses increases our } \\
\text { understanding of medical and surgical patients }\end{array}$ & $3.58 \pm 1.08$ & $3.53 \pm 0.97$ & $\mathrm{t}$ \\
\hline $\begin{array}{l}\text { The pursuit of psychiatry permits the } \\
\text { development of really rewarding relationships } \\
\text { with people }\end{array}$ & $3.67 \pm 0.85$ & $3.67 \pm 0.96$ & $22.52 \pm 2.66$ \\
\hline Total Score & $22.47 \pm 2.64$ & $\mathrm{t}=0.132, \mathrm{P} 0.896$ \\
\hline
\end{tabular}


Table 6:- Average scores of the items of the attitude of the studied students towards psychiatric treatment and hospitals before and after studying the course.

\begin{tabular}{|l|l|l|l|}
\hline Items & Before & After & Significance test \\
\cline { 2 - 3 } & Mean \pm SD & Mean \pm SD & \\
\hline $\begin{array}{l}\text { Psychiatric hospitals are little more than } \\
\text { prisons }\end{array}$ & $1.96 \pm 0.84$ & $2.21 \pm 0.94$ & $\mathrm{t}=1.583, \mathrm{P} 0.118$ \\
\hline $\begin{array}{l}\text { It is quite easy for me to accept the efficacy of } \\
\text { psychotherapy }\end{array}$ & $3.43 \pm 1.10$ & $3.44 \pm 0.86$ & $\mathrm{t}=0.096, \mathrm{P} 0.924$ \\
\hline $\begin{array}{l}\text { The different forms of therapy that are } \\
\text { available today most mental ill patients } \\
\text { improve }\end{array}$ & $3.77 \pm 0.83$ & $3.64 \pm 0.90$ & $\mathrm{t}=0.837, \mathrm{P} 0.405$ \\
\hline $\begin{array}{l}\text { Psychiatric treatment causes patients to worry } \\
\text { much about their symptoms }\end{array}$ & $2.64 \pm 1.19$ & $2.185 \pm 104$ & $\mathrm{t}=1.038, \mathrm{P} 0.303$ \\
\hline $\begin{array}{l}\text { Psychiatrist has very little to do to help their } \\
\text { patients }\end{array}$ & $2.51 \pm 1.00$ & $2.91 \pm 1.06$ & $\mathrm{t}=2.165, \mathrm{P} 0.034$ \\
\hline $\begin{array}{l}\text { Psychiatric hospitals have a specific } \\
\text { contribution to make to the treatment of the } \\
\text { mentally ill }\end{array}$ & $3.64 \pm 1.02$ & $3.32 \pm 0.97$ & $\mathrm{t}=0.735, \mathrm{P} 0.465$ \\
\hline $\begin{array}{l}\text { There is no evidence about the effectiveness } \\
\text { of psychotherapy since it is fraudulent }\end{array}$ & $2.54 \pm 0.84$ & $3.03 \pm 1.06$ & $\mathrm{t}=2.944, \mathrm{P} 0.004$ \\
\hline $\begin{array}{l}\text { Psychiatric treatment has been more effective } \\
\text { in the recent year }\end{array}$ & $3.82 \pm 0.83$ & $3.52 \pm 0.93$ & $\mathrm{t}=2.553, \mathrm{P} 0.013$ \\
\hline Total Score & $24.14 \pm 3.03$ & $24.96 \pm 2.49$ & $\mathrm{t}=1.509, \mathrm{P} 0.136$ \\
\hline
\end{tabular}

Table 7:- Comparison of the average total attitude score of the studied students before and after studying the course

\begin{tabular}{|l|l|l|l|}
\hline \multirow{2}{*}{ Items } & Before & After & Significance test \\
\cline { 2 - 3 } & Mean \pm SD & Mean \pm SD & \\
\hline Total attitude score & $92.67 \pm 7.90$ & $95.34 \pm 8.32$ & $\mathrm{t}=1.822, \mathrm{P} 0.079$ \\
\hline
\end{tabular}

Table 8:- The relationship between total attitude score and socio-demographic characteristics of the studied students

\begin{tabular}{|c|c|c|c|c|c|}
\hline \multirow[t]{2}{*}{ Character } & \multirow[t]{2}{*}{ Items } & \multicolumn{2}{|c|}{ Before } & \multicolumn{2}{|c|}{ After } \\
\hline & & No & Mean \pm SD & No & Mean \pm SD \\
\hline \multirow[t]{2}{*}{ Sex } & Males & 14 & $96.00 \pm 9.45$ & 14 & $92.43 \pm 5.81$ \\
\hline & Females & 60 & $91.72 \pm 7.18$ & 56 & $96.07 \pm 8.72$ \\
\hline \multicolumn{2}{|c|}{ Significance test } & \multicolumn{2}{|c|}{$\mathrm{t}=1.889, \mathrm{P} 0.063$} & \multicolumn{2}{|c|}{$\mathrm{t}=1.479, \mathrm{P} 0.144$} \\
\hline \multirow{2}{*}{ Residence } & Rural & 64 & $92.81 \pm 8.02$ & 61 & $95.14 \pm 8.51$ \\
\hline & Urban & 10 & $90.70 \pm 5.92$ & 9 & $96.67 \pm 7.09$ \\
\hline \multicolumn{2}{|c|}{ Significance test } & \multicolumn{2}{|c|}{$\mathrm{t}=0.797, \mathrm{P} 0.428$} & \multicolumn{2}{|c|}{$\mathrm{t}=0.509, \mathrm{P} 0.570$} \\
\hline \multirow[t]{4}{*}{ SES } & Very low & 18 & $87.22 \pm 3.98$ & 18 & $94.00 \pm 5.84$ \\
\hline & Low & 18 & $94.33 \pm 8.31$ & 15 & $99.40 \pm 10.74$ \\
\hline & Moderate & 18 & $91.72 \pm 5.73$ & 17 & $94.59 \pm 9.18$ \\
\hline & High & 20 & $96.40 \pm 8.98$ & 20 & $94.15 \pm 6.92$ \\
\hline \multicolumn{2}{|c|}{ Significance test } & \multicolumn{2}{|c|}{$\mathrm{F}=5.787, \mathrm{P} 0.001$} & \multicolumn{2}{|c|}{$\mathrm{F}=1.568, \mathrm{P} 0.205$} \\
\hline
\end{tabular}

\section{Discussion:-}

The result of this study revealed statistically significant improvement in the nursing student's attitude towards psychiatric patients and mental illness after the psychiatric nursing course; this means that the course was able to produce positive change towards the students' overall attitudes towards people with mental illness. This finding is consistent with previous researches revealing that nursing student's attitudes towards mental illness and psychiatric

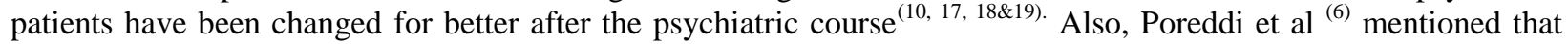
nursing students have significant positive attitudes toward mental illness and they agreed that psychiatric ill patients can enjoy them personal and social life events such as marriage, working, having children or family. However this finding is inconsistent with research indicating that students attitudes toward mentally ill patients show no change after clinical contact ${ }^{(20)}$ as suggested by Singh et al ${ }^{(21)}$ changing attitudes involves a complex process, depending on many factors rather than patient contact alone. 
The findings of the current study indicated that there is no statistically significant improvement between the students' attitudes towards psychiatry and psychiatrists and four items are constructed to measure the attitude in this direction. This result is consistent with the finding of Subedi et al ${ }^{(22)}$ who found that lack of interest for psychiatry among students is related to insufficient hours, inadequate staff and poor planning of curriculum. Also students considered psychiatrists as unstable persons and think of them as unable of having a stable relationship and they are not different from their patients. Wakil et al ${ }^{(23)}$ Believed that nursing students have negative attitudes towards psychiatry and these negative attitudes include stigma and ignorance about mental illness and its etiology. Beside that other still believe that mental illness caused due to super nature etiology. This route didn't differ a cross socio economic classes and not affected by educational background, thus reflect the pervasiveness of this belief in the society. However, Happell \& Gaskin ${ }^{(11)}$ found that psychiatry component of the nursing course improved the attitude of the students toward discipline.

The present study showed no statistically significant improvement in the total score of the nursing student's attitude toward psychiatric knowledge and teaching but out of 7 items only three showed significantly improvement, According to Parikh et al ${ }^{(24)}$ most of the studied students believed that psychiatry has very little scientific information and they are uncertain about the importance of psychiatric curriculum, however one - third found their undergraduate psychiatric training to be of value. McLaughlin ${ }^{(25)}$ Found that nursing students generally have positive attitudes toward psychiatric ill patients, and that clinical contact can cause change in student attitudes, in either a positive or negative way. The findings are inconsistent with research indicating that student attitudes show no change after clinical contact ${ }^{(20)}$.

According to the present study there is no statistically significant improvement in the total score of the nursing students attitudes toward psychiatric treatment and hospitals, however only three items showed significant improvement, Parikh et al ${ }^{(24)}$ found that the students shows agreement about the importance of psychiatric treatment and they consider psychiatric hospitals are essential for the treatment of psychiatric ill patients, this finding contradict the finding of Malhi et al ${ }^{(26)}$ who mentioned that nursing students view psychiatry as less scientific and having fewer clinically effective treatment. Sartorius et al ${ }^{(27)}$ mentioned five misconception about psychotropic drugs that he thought to be the reason for the negative attitude toward psychiatric treatment, they are addictive, sedative, not curing, merely treating patients and ineffective in preventing relapse.

Previous researches focused on exposure to psychiatric theory and practice improve students attitude, however exposure to psychiatry did not increase the likelihood of choosing a career in psychiatry ${ }^{(3 \& 28)}$, these results contradict the results of the present study in which the nursing students intention to choose psychiatric nursing as a career has been improved after the psychiatric nursing course.

\section{Conclusion:-}

The result of the present study proved that the total attitude score of the nursing students attitude towards psychiatric patients has been slightly improved, also the students intention to choose psychiatric nursing as a career has been improved after the psychiatric nursing course.

\section{Recommendations:-}

According to the result of the present study it is recommended to:

$>$ Continue improving teaching conditions and continue evaluating it in order to improve the care of mentally ill patients.

$>$ Provide creative approaches to clinical education such as simulation can potentially be the key in helping students feel more comfortable with mental illness, helping them feel better prepared for their mental health practicum, decrease their anxiety levels, decrease stereotypical attitudes, and increase their knowledge.

$>$ Further research can be done to examine how the nursing students interact with mentally ill patients to assess if there is consistency between belief and behavior.

$>$ Comparative study can be done among the different grads to get broader view about the nursing students' attitudes towards psychiatry and mental illness. 


\section{Reference:-}

1. Randolph, N. (2002). Springhouse Review for Psychiatric \& Mental Health Nursing Certification. BOOK, Lippincott Williams \& Wilkins. Retrieved from https://books.google.com.eg/books?id=q7tYLkbOgKAC

2. Wright, R. (2012). Effective Communication Skills for the "Caring " Nurse. The Great Teachers Tertiary Place, 2010-2012.

3. Balhara, Y. P. S., \& Mathur, S. (2013). A Comparative Study of Attitudes Toward Psychiatry Among Nursing Students Across Successive Training Years. Indian Journal of Psychological Medicine, 35(2), 159-166. JOUR. http://doi.org/10.4103/0253-7176.116246

4. Hooper, M.-E., Browne, G., \& O’Brien, A. P. (2016). Graduate nurses' experiences of mental health services in their first year of practice: An integrative review. International Journal of Mental Health Nursing, 25(4), 286298. JOUR. http://doi.org/10.1111/inm.12192

5. Rezler, A. G. (1976). Methods of attitude assessment for medical teachers. Medical Education, 10(1), $43-51$. Journal Article.

6. Poreddi, V., Thimmaiah, R., Pashupu, D. R., Ramachandra, \& Badamath, S. (2014). Undergraduate Nursing Students' Attitudes towards Mental Illness: Implications for Specific Academic Education. Indian Journal of Psychological Medicine, 36(4), 368-372. JOUR. http://doi.org/10.4103/0253-7176.140701

7. Poreddi, V., Thimmaiah, R., \& Math, S. B. (2015). Attitudes toward people with mental illness among medical students. Journal of Neurosciences in Rural Practice, 6(3), 349-354. JOUR. http://doi.org/10.4103/09763147.154564

8. Mårtensson, G., Jacobsson, J. W., \& Engström, M. (2014). Mental health nursing staff’s attitudes towards mental illness: an analysis of related factors. Journal of Psychiatric and Mental Health Nursing, 21(9), 782788. JOUR. http://doi.org/10.1111/jpm.12145

9. Rahmani, F., Ranjbar, F., Ebrahimi, H., \& Hosseinzadeh, M. (2015). The Effects of Group Psychoeducational Programme on Attitude toward Mental Illness in Families of Patients with Schizophrenia, 2014. Journal of Caring Sciences, 4(3), 243-251. JOUR. http://doi.org/10.15171/jcs.2015.025

10. Dawud, E. (2012). Impact of Clinical Placement on Nursing Students' Attitudes towards Psychiatry. Journal of American Science, 8(2), 627-632.

11. Happell, B., \& Gaskin, C. J. (2013). The attitudes of undergraduate nursing students towards mental health nursing: a systematic review. Journal of Clinical Nursing, 22(1-2), 148-158. Journal Article, Review. http://doi.org/10.1111/jocn.12022

12. Alpaslan, A., Kocak, U., CoskunO, K., Ozbulut, O., \& Yesil, A. (2015). Attitude towards Psychiatry and Its Possible Association to Alexithymia among Medical Students. Journal of Mood Disorders, 1. http://doi.org/10.5455/jmood.20150420075513

13. Triguero Veloz Teixeira, M. C., de Freitas Marino, R. L., \& Rodrigues Carreiro, L. R. (2015). Associations between Inadequate Parenting Practices and Behavioral Problems in Children and Adolescents with Attention Deficit Hyperactivity Disorder. The Scientific World Journal, 2015, $683062 . \quad$ JOUR. http://doi.org/10.1155/2015/683062

14. Dissanayaka, T. D., Marambe, D. K. N., \& Liyanage, E. (2013). Physiotherapy students' perception on problem based learning. Sri Lanka Journal of Bio-Medical Informatics, 3(3), 75-81. http://doi.org/10.4038/sljbmi.v3i3.4787

15. El-Gilany, A., El-Wehady, A., \& El-Wasify, M. (2012). Updating and validation of the socioeconomic status scale for health research in Egypt. Eastern Mediterranean Health Journal = La Revue de Sante de La Mediterranee Orientale = Al-Majallah Al-Sihhiyah Li-Sharq Al-Mutawassit, 18(9), 962-968. Journal Article, Validation Studies

16. Burra, P., Kalin, R., Leichner, P., Waldron, J. J., Handforth, J. R., Jarrett, F. J., \& Amara, I. B. (1982). The ATP 30-a scale for measuring medical students' attitudes to psychiatry. Medical Education, 16(1), 31-38. Journal Article, Research Support, Non-U.S. Gov't.

17. Hellebusch, E. S. (1989). The effect of practicum on student attitude toward mental illness. University of Cincinnati, Cincinnati.

18. Murray, M., \& Chambers, M. (1991). Effect of contact on nursing students' attitudes to patients. Nurse Education Today, 11(5), 363-367. JOUR. http://doi.org/http://dx.doi.org/10.1016/0260-6917(91)90036-A

19. Slimmer, L. W., Wendt, A., \& Martinkus, D. (1990). Effect of psychiatric clinical learning site on nursing students' attitudes toward mental illness and psychiatric nursing. The Journal of Nursing Education, 29(3), 127-133. Clinical Trial, Journal Article, Randomized Controlled Trial, Research Support, Non-U.S. Gov’t.

20. Weller, L., \& Grunes, S. (1988). Does contact with the mentally ill affect nurses; attitudes to mental illness? British Journal of Medical Psychology, 61(3), 277-284. JOUR. http://doi.org/10.1111/j.2044- 
8341.1988.tb02789.x

21. Singh, S. P., Baxter, H., Standen, P., \& Duggan, C. (1998). Changing the attitudes of "tomorrow"s doctors' towards mental illness and psychiatry: a comparison of two teaching methods. Medical Education, 32(2), 115120. Journal Article.

22. Wakil, M. A., Abdulmalik, J., Salawu, F., \& Ahidjo, A. (2009). Attitude of nursing students towards psychiatry as an area of specialization. BoMj, 6(2), 1-14.

23. Subedi, S., Aich, T. K., Shah, S., \& Thapa, D. K. (2013). Non-psychiatry consultant 's attitude towards psychiatry : a study from universal college of medical sciences, nepal. Universal College of Medical Sciences, 1(4), 2-6. (Wakil, Abdulmalik, Salawu, \& Ahidjo, 2009)

24. Parikh, N. C., Sharma, P. S., Chaudhary, P. J., Gandhi, H. A., \& Banwari, G. H. (2014). Study of attitude of interns toward psychiatry: A survey of a tertiary level hospital in Ahmedabad. Industrial Psychiatry Journal, 23(2), 143-148. JOUR. http://doi.org/10.4103/0972-6748.151690

25. McLaughlin, C. (1997). The effect of classroom theory and contact with patients on the attitudes of student nurses towards mentally ill people. Journal of Advanced Nursing, 26(6), 1221-1228. JOUR. http://doi.org/10.1046/j.1365-2648.1997.00463.x

26. Malhi, G. S., Parker, G. B., Parker, K., Carr, V. J., Kirkby, K. C., Yellowlees, P., ... Tonge, B. (2003). Attitudes toward psychiatry among students entering medical school. Acta Psychiatrica Scandinavica, 107(6), 424-429. JOUR. http://doi.org/10.1034/j.1600-0447.2003.00050.x

27. Sartorius, N., Gaebel, W., Cleveland, H.-R., Stuart, H., Akiyama, T., Arboleda-Flórez, J., ... Tasman, A. (2010). WPA guidance on how to combat stigmatization of psychiatry and psychiatrists. World Psychiatry, 9(3), 131-144. JOUR. Retrieved from http://www.ncbi.nlm.nih.gov/pmc/articles/PMC2948719/

28. Edward, K., Warelow, P., Hemingway, S., Hercelinskyj, G., Welch, A., McAndrew, S., \& Stephenson, J. (2015). Motivations of nursing students regarding their educational preparation for mental health nursing in Australia and the United Kingdom: a survey evaluation. BMC Nursing, 14, $29 . \quad J O U R$. http://doi.org/10.1186/s12912-015-0084-8 